\title{
R. K. Narayan's The Guide as a Lesson of Life
}

\author{
Mrs. Sangeeta Mondal \\ Assistant Professor, English \\ Basirhat College \\ Basirhat, West Bengal, India \\ sangeetamondal007@gmail.com
}

\begin{abstract}
Narayan through his precepts and examples tried to teach his readers like a prophetic novelist and suggested that the novel can be interpreted as a lesson of life for it teaches us how to be successful in life but at the same time teaches us how to avoid the various pitfalls which might come in the long run. Raju's life is exemplary as it can be both of guiding and misguiding and solely depends on the follower which path he/she would like to follow. This novel is a classic statement on the improvement of human conduct - on ambition and human restraint as Raju becomes symbolic both of selfish individualism and the saviour of mankind. The theme of the quest for spiritual fulfilment, is one of the leading themes of the novel, because in Hindu cosmology, the path to spiritual illumination requires mentoring from a 'guru' or guide. Narayan wanted to guide the readers through Raju that man does not experience real pleasure or happiness in restful rusty position but in suffering and striving for ideals - for the welfare of others in which lies the essence and dignity of life. It is a search for the true identity and authentic self that Narayan wants to establish through the character of Raju.
\end{abstract}

Keywords: Ambition, Crime, Imprisonment, Lesson, Welfare, Sacrifice, Saviour.

"Some are born great, some achieve greatness, and some have greatness thrust upon them." 
R. K. Narayan's The Guide was first published in 1958. Being one of the most acclaimed works in Indian fiction, Narayan was conferred upon the Sahitya Akademi Award in the year 1960 for his novel The Guide which has been translated into many languages of the world. Modern critics have come to see it as a triumph of art which does not remain specifically confined to matters of narrative or style but remains embedded in the theme or vision of the novel which sums up the title The Guide. The word 'guide' has literally three meanings - firstly, a person, who shows others the way; secondly, a person employed to point out important sites on a journey or a visit; and lastly, an advisor or counsellor who directs or influences the behaviours of others. There are, of course, multiple puns on the word 'guide'. All the meanings are inextricably bound with Raju in The Guide because Raju's journey from a shopkeeping boy to a tour guide to Rosie's guide or mentor, and finally to a spiritual guide of the villagers of Mangal is the story of the novel. The theme of the quest for spiritual fulfilment, is one of the leading themes of the novel, because in Hindu cosmology, the path to spiritual illumination requires mentoring from a 'guru' or guide. Raju, a railway guide whose sole motif was to extort money from the tourists for himself, as a lover to Rosie becomes hedonist, goes to jail, does something good for the prisoners, becomes a swami and undertakes a fast for the welfare of others. Narayan wanted to guide the readers through Raju that man does not experience real pleasure or happiness in restful rusty position but in suffering and striving for ideals - for the welfare of others in which lies the essence and dignity of life. It is a search for the true identity and authentic self that Raju wants to prove in the novel.

The main protagonist of the novel Raju begins his life as a shop-keeper on the railway platform. Soon he accumulates knowledge about Malgudi by going through various journals 
and magazines kept in his stall and gradually becomes famous as a tourist guide called 'Railway Raju'. One day Rosie and her husband, Marco comes to Malgudi -- Raju notices that Marco is ignoring his wife who is very beautiful and is interested in dead and decaying things. Unlike Marco, Raju cares about Rosie's motivations, feelings, sentiments, tastes and dispositions. He becomes the guide of a single family from a tourist guide, and starts to spend most of his time with Rosie. Raju betrays Marco who had great trust and confidence in him. When Marco comes to know about their liaison, he becomes exceptionally irate and leaves Rosie forever. Rosie comes to stay at Raju's house but Raju's mother is against this illicit affair and considers her responsible for ruining her son's life and leaves her own house. Later Rosie becomes a famous dancer, earns a lot of money and they both begin to lead a lavish lifestyle but Raju gets addicted to drinking and gambling and the gap between Rosie and Raju is widened.

Raju is driven by greed and insecurity and forges the signature of Rosie on a document, and is taken to the court of law by Marco. Rosie arranges a lawyer for Raju and pays him lot of money to plead for Raju in the court but at the same time severs all relations with him. Raju is punished for forging the signature of Rosie and spends two years in jail. Raju becomes a spiritual guide, after coming out of jail and takes shelter in an old temple by the Saryu River, near a village Mangal. Velan, a common villager seeks his counsel on a family matter and Raju's counsel miraculously solve his family problem. Gradually the villagers begin to have faith in Raju and offer him gifts. Soon there arises a drought in the village and Raju decides to fast for until he can appease the rain god and bring rain. This fasting is being thrusted on him by fate but he also undertakes it out of love for the villagers. On the last day of the fasting Raju "sagged down" due to fatigue and hunger, and signs of rain could be felt by Raju. R. K. Narayan does not clearly mention the end of Raju but the novel shows a deceitful person turning into a saint out of compulsion. In fact, the 
circumstances which landed him in jail are his own creation, but after coming out of jail his fate was thrust upon him and he is redeemed by his last act of martyrdom.

Narayan's title focuses upon the life and career of Raju as a 'tour guide' in the first part of the novel. He started his career as a small shopkeeper, but within a short span his eloquence, common sense, knowledge and judgement make him the 'Railway Raju':

"I came to be called Railway Raju. Perfect strangers, having heard of my name, began to ask for me when their train arrived at the railway station." (55)

He soon acquires bits of information browsing through old journals, magazines and periodicals which he used to keep in his shop. He is not only intelligent and observant but also a shrewd judge of human character. He captivated his clients with his manners, common sense as well as providing them information regarding Malgudi, its scenic beauty and important sites. He also arranges for the tourists boarding, lodging and transportation. His popular charm made him 'Railway Raju' whom the tourists come to and he in turn leads them to their destination. Raju acquires detailed knowledge about Malgudi and its whereabouts by talking with the tourists and gathering tit-bits of knowledge from tourist magazines and using it for his own advantage. His aptitude to cater to the tastes and needs of the tourists is praiseworthy. At the same time, his understanding of human psychology is profound and he manages to escape by making vague and ambiguous statements about things which he does not know. He never says "no":

“I never said, 'I don’t know.' Not in my nature, I suppose.” (55)

He deceits the tourists by giving them false information, cheats them successfully and becomes famous as a tourist guide:

"I said, 'Oh, yes, a fascinating place. Haven't you seen it? You must find the time to visit it, otherwise your whole trip here would be a waste.' I am sorry I said it, an utter falsehood, but only because I wanted to be pleasant." (55) 
Soon Raju becomes a 'model guide' in the small town of Malgudi and those who intend to be in the same profession soon begin to follow Raju as a 'model guide'. Narayan has portrayed Raju almost as a born guide — a symbol of common sense and wisdom. Raju, the guide is destined to be a guide by chance and temperament. As a tour guide, he is impulsive, unprincipled, and self-indulgent.

The deliberation of various events brings about a change in Raju's career. Rather than being a guide to the general tourists who arrive at Malgudi, Raju becomes the 'guide of a single family' -- the family of Rosie and her husband Marco, who comes there for some diversion and pleasure. Marco is immediately pleased with the service of Raju and engages him as their personal guide. Soon he comprehends that Marco and Rosie are not in good terms. This in turn leads to a relationship between Raju and Rosie as he takes her by storm and wins her heart. Raju proves himself to be an adept lady-killer by exploiting his seductive charms and play the game of love with Rosie by paying her bold compliments, smooth talk and flattery, and fuels her ambition to be a great dancer:

"I smiled affably, my best smile, as if I had been asked for it by a photographer." (72)

“Don't you know my voice? Didn't I come with you yesterday to that cobra man? All night I didn't sleep, ... The way you danced, your form and figure haunted me all night."

In this field also Raju becomes a 'model guide' who imparts valuable lessons in the art of love-making which enthralls and mesmerizes Rosie. This occurs in a split in the husbandwife relationship and Raju's prolonged affair with Rosie begins and Raju starts a new phase of life as an adulterous lover.

The next role played by Raju is that of an impresario or the 'guide of a dancer.' Since he is a professional guide and pretends to be a connoisseur of art, Raju is much aware of the value of a dancer. He is not driven by love but by mean mercenary motives, a feeling of 
sensuality for Rosie. The surface Raju soon becomes the reality of Raju and is exposed to the readers. Hence an implied irony is there when he is looked upon as a spiritual guide - a conflict between illusion and reality, between mask and the face. Mask cannot be the face of reality; likewise, professional and spiritual guide are both contrary to each other. When Marco leaves Rosie and she comes to stay with Raju, we find Raju in the role of the 'guide of a dancer.' He undertakes and supervises her training and practice of dancing, launches her career as a professional dancer, and guides her by becoming her stage manager and impresario. He helps her in all possible ways to build up her career, managing both her personal and professional affairs. Soon she becomes a renowned dancer and her fame spreads far and wide. Rosie's involvement with dance results in seclusion and loss of communication with Raju and results in his bewilderment. They begin to earn a lot of money and lead a lavish lifestyle. His tactful way of handling of Rosie's career and his shrewd business dealings can be a lesson for those who want to step into the shoes of Raju. However, his love and possessiveness for Rosie and jealousy for Marco motivate him to hide the book which Marco had sent for Rosie:

"I thought it would be best to put the book away. I carried it to my most secret, guarded place in the house--- the liquor chest, adjoining the cardroom, the key of which I carried next to my heart--- stuffed the volume out of sight, and locked it up. Nalini never went near it. I did not mention the book to her ...But it was like hiding a corpse." (199) He forges Rosie's signature out of insecurity because he did not want her to realize Marco's generosity:

"What was the man's purpose in sending it now? Why this sudden generosity to return her an old box? Was he laying a trap for her, or what was it? (206) 
Raju had thought that Rosie would break down with Raju's imprisonment and jail but Rosie remained unperturbed and unmoved. Perhaps she was shocked at being betrayed by the person she had trusted the most:

"She listened to me as if I were addressing a stone pillar. Even now I can recollect her bewilderment, stunned expression as she tried to comprehend the situation. I thought she would break down. She often broke down on small issues, but this seemed to leave her unperturbed. She merely said, 'I felt all along you were not doing right things. This is karma. What can we do?' "'(216)

She does not forgive Raju for the crime he has committed but out of love or sense of duty she tried her best to do whatever she could do for Raju--- arrange for a good lawyer who could plead the case of Raju in court. But in spite of that he was sentenced to two years of imprisonment:

"Our star lawyer looked gratified, I should properly have got seven years according to law books, but his fluency knocked five years off, though, if I had been a little careful..."

His continuous playing of roles one after the other makes him unaware of the extent of his act and his confidence ironically lands him in jail. Much knowledge can be gained from Raju as one can also take lesson from his mistakes that a man should not adopt dishonest means out of jealousy and insecurity for it is sure to land him in jail. The fact that entering a profession also means to make one an observer and should enable him to judge human character otherwise enigmatic people like Marco may be plotting and laying traps. The 'guide' Raju has, once again, a fall as greed overtakes his balance and misguide his sensibilities.

Raju's well-mannered, hard-working and helpful behaviour makes him a 'model prisoner' in jail. He is quite at ease in jail and is surprised when he comes to know that people are afraid 
of prison. His life in jail is so comfortable that he becomes very depressed when the news of his release comes. He comes out of jail with fear in his mind and regrets in his heart and thus sets an example for all the prisoners:

"I felt amused at the thought of the ignorant folk who were horrified at the idea of a jail... I felt choked with tears when I had to go out after two years, and I wished that we had not wasted all that money on our lawyer. I'd have been happy to stay in this prison permanently." (228)

Raju's life is also a lesson for the prisoners in this respect and becomes the light bearer of those who want to follow his footsteps.

After coming out of jail, the role of a 'swami' was almost thrusted on Raju. When he was sitting alone near a dilapidated temple after his release from jail, a villager called Velan who seemed to be impressed by his saintly appearance talks frankly to Raju about the problem which was worrying him and sought for his advice and guidance:

“... Raju was sitting cross-legged as if it were a throne, beside an ancient shrine.” (5)

Raju on the other hand is tempted to play the role of the swami because---

"it was in his nature to get involved in other people's interest and activities." (9) Velan, the simple villager, takes him to be a wise man, a 'swami' and a spiritual guide. Though a fake one, Raju's impressive way of talking and his simple philosophy soon make him appear as a real guru:

"If you show me a person without a problem, then I'll show you the perfect world. Do you know what the great Buddha said?... if you show me a single home without a problem, I shall show you the way to attain a universal solution to all problems." (15) He also exploits the simple faith of the villagers and thus manages food for himself: 
"Food was coming to him unmasked now. If he went away somewhere else certainly nobody was going to take the trouble to bring him food in return for just waiting for it."

But almost unconsciously a transformation comes over the fake 'swami'. Raju may be compared to the highway robber Ratnakara who later transformed into a sage and came to be known as Maharishi Valmiki, the composer of Ramayana. But the point of difference lies in the fact that Ratnakara became a robber to feed his family but Raju adopted dishonest means to feed his greed. The affection and devotion of the common villagers brings about a transformation in Raju's inner self to such an extent that he assumes the role of a spiritual guide by making mystifying statements and elevating himself to a larger-than-life figure:

"He realised that he had no alternative: he must play the role that Velan had given him."

The uneducated and simple-minded villagers are impressed by his charming words and his fame as a 'sadhu' or saint spread far and wide and devotees begin to visit him with various kinds of gifts and offerings. The blind faith of the people of Mangal converts Raju into an instrument of their will. When he is approached to fast by his devotees, and thus to bring rains to the droughted land, he realizes that he has pushed himself into such a position from which he could not pull himself out. Raju is compared to Mahatma Gandhi by one of the villagers:

"This Mangal is a blessed country to have a man like the Swami in our midst. No bad thing will come to us as long as he is with us... If he fasts there will be rain. Out of his love for us he is undertaking it. This will surely bring rain and help us. Once upon a time a man fasted for twenty-one days and brought down the deluge. Only great souls that take upon themselves tasks such as this_-" (103) 
He makes an attempt to escape from this situation by confessing to Velan all about his bitter past but Velan's simple-mindedness and trust on him is so profound that he refuses to believe him. He becomes a genuine spiritual guide, a martyr for the cause of humanity:

“ 'Velan, it's raining in the hills. I can feel it coming up under my feet, up my legs- - He sagged down." (247)

He sacrificed his life for the welfare of the villagers. Thus, from a confident, ignorant and selfish guide, Raju raises himself to the level of an altruistic and self-effacing guide. After his transformation as a holy man, he is cautious, thoughty, and self-controlled.

Narayan tries to bring forth the theory that the same set of qualities can make a person successful both as a tourist guide and as a spiritual guide whom we can follow. The protagonist plays the social role of a guide that is conferred on him in the early stages of his career. Narayan through his precepts and examples tried to teach his readers like a prophetic novelist and suggested that the novel can be interpreted as a lesson of life for it tells us both how to be successful and at the same time how to avoid the various pitfalls which might come in the way of one's success. Raju's life is exemplary as it can be both of guiding and misguiding and solely depends on the follower which path he/she would like to follow. Raju who wanted to hide himself from the world due to his misconduct and jail chose to stay in Mangal becomes famous for his good conduct from this village as a saint or 'swami'. This novel is a classic statement on the improvement of human conduct - on ambition and human restraint as Raju becomes symbolic both of selfish individualism and the saviour of mankind. The novel is also ethical as it is the story of a man who proceeds from egotism to altruism via psychological egoism. Raju, a railway guide whose sole motif was to extort money from the tourists for himself, as a lover to Rosie becomes hedonist, goes to jail, does something good for the prisoners, becomes a swami and undertakes a fast for the welfare of others. Narayan wanted to guide the readers through Raju that man does not experience real pleasure or 
happiness in restful rusty position but in suffering and striving for ideals - for the welfare of others in which lies the essence and dignity of life. It is a search for the true identity and authentic self that Raju wants to prove in the novel. 


\section{Works Cited}

Narayan, R.K. The Guide. Indian Thought Publications, 1999.

Iyengar, Srinivasa. Indian Writings in English. New Delhi, 1994.

Kumar, A.Phaniraja. R.K. Narayan's 'The Guide’ a story of poly-guide. 